\title{
Water quality analysis and simulation
}

\author{
Ielizaveta Dunaieva ${ }^{1}$, Valentyna Popovych $^{1}$, Valentyn Vecherkov ${ }^{1}$, Ekaterina Golovastova ${ }^{1}$, \\ Vladimir Pashtetskyi ${ }^{1}$, Aleksandr Melnichuk ${ }^{2}$, Wilfried Mirschel $^{3}$, Vitaly Terleev ${ }^{4}$, \\ Aleksandr Nikonorov ${ }^{4, *}$, Issa Togo ${ }^{4}$, Yulia Volkova ${ }^{4}$, and Dmitry Shishov ${ }^{5}$ \\ ${ }^{1}$ Federal State Budget Scientific Institution «Research Institute of Agriculture of Crimea», Kievskaya, \\ 150, Simferopol, 295453, Crimea \\ ${ }^{2}$ V.I. Vernadsky Crimean Federal University, Vernadskogo pr., 4, Simferopol, 295007, Crimea \\ ${ }^{3}$ Leibniz-Centre for Agricultural Landscape Research, Eberswalder Straße 84, Müncheberg, 15374, \\ Germany \\ ${ }^{4}$ Peter the Great St. Petersburg Polytechnic University, Polytechnicheskaya, 29, St. Petersburg, \\ 195251, Russia \\ ${ }^{5}$ St.Petersburg State Agrarian University, Peterburgskoyeshosse, 2, St. Petersburg-Pushkin, 196601, \\ Russia
}

\begin{abstract}
The actuality of the study is caused by the needs of water resources state assessment, which natural supply is insufficient. The article analyzes the quality of surface water and groundwater using processed statistical data and the results of mathematical modeling in the GIS environment. The results showed that the quality of water sources under current anthropogenic load is normal, but subsequent monitoring of the situation is required. There is no significant relationship between the quality of surface water and groundwater.
\end{abstract}

\section{Introduction}

The river network of the Crimean Peninsula is represented by 1657 rivers, streams, and beams with a total length of $5,996 \mathrm{~km}$ (density of the river network is $0.22 \mathrm{~km} / \mathrm{km} 2$ ). All rivers, except Salgir, refer to a small rivers and streams. The average annual river flow [1] is $0.910 \mathrm{~km}^{3} /$ year. Expected reserves of underground water resources of Crimea [2] are $0.47 \mathrm{~km}^{3} /$ year (1.28 million $\mathrm{m}^{3} /$ day). According to the Falkenmark index [3], Crimea refers to regions with a significant shortage of the local water resources (population is equal to $1,913,731$ people according to the Federal State Statistics Service Office for the Republic of Crimea and the city of Sevastopol on 01.01. 2018), which is equal to 450 cubic meters per person annually. In connection with this fact, research about the evaluation of the water resources quality is especially urgent in order to exclude the influence of negative factors on their condition.

\section{Materials and methods}

\footnotetext{
* Corresponding author: coolhabit@yandex.ru
} 
The area of the research is the land of Krasnogvardeisky district, which is located in the central part of the Crimean Peninsula (Fig. 1). According to the geomorphologic zoning of the Crimea, the territory of the region belongs to the North Crimean (Taurian) accumulative plain, which altitude is $10-40 \mathrm{~m}$ above sea level.

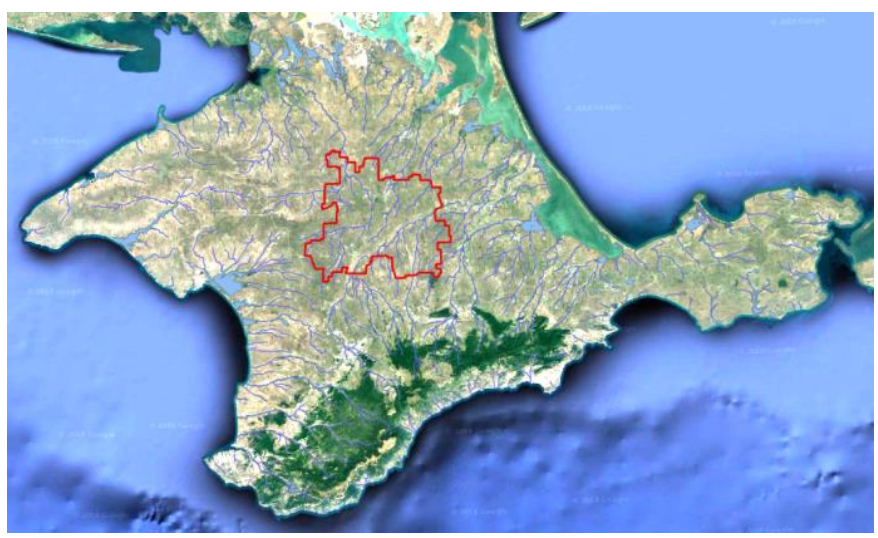

Fig. 1. Map of the territory.

The surface of the area has a character of the wide-wavy plain. The flatness of the territory is often disturbed by the wide balconies and ravines, which are extended in the direction from the south to the north and the northeast. Figure 2 shows relief of the territory by DEM processing (SRTM $30 \mathrm{~m}$ ) in QGIS 2.18.

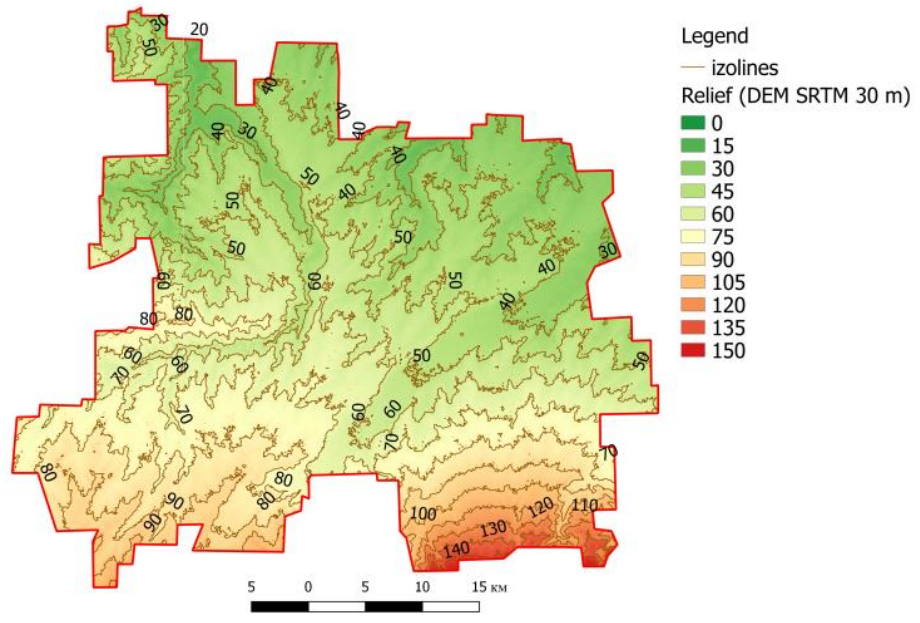

Fig. 2. Relief of the territory

The climate of the territory is steppe, moderately cold, semi-dry, continental, with the large annual and daily temperature fluctuations. Autumn is warm, dry and long. Winter is moderately mild, the snow cover time is slight and short. Spring is usually dry, cold winds are frequent and strong. Summers are hot, the maximum temperature in July-August can rise to $35-40^{\circ} \mathrm{C}$. Rains are rare, torrential, short-living. The annual precipitation is $426 \mathrm{~mm}$ according to the average long-term data of the Klepinino meteorological station.

The territory is located on the accumulative-denudation elevated gently sloping plain with a powerful subaerial cover (Fig.3). Soil-forming rocks are Upper Pleistocene eluvialdeluvial and formed by the eolovodiluvial loess-like loams. At a greater depth, they are 
underlained by Neogene (Pliocene) sands and conglomerates. Groundwater is located deeply (about 20-30 m). Since the middle of the last century, groundwater has remained approximately at the same depth during the entire period of irrigation, with no influence on the soil formation. The soil cover is represented by chernozems, more precisely by the southern low-humus medium-thick heavy or loess-like loams (according to the classification of USSR soils) [4].

There are 98 ponds in Krasnogvardeysky district, 21 of which are used for irrigation, 1 for recreation, 20 - for storage ponds, 4 - for complex facilities and 49 are not used. The total volume of ponds is 6178.74 thousand $\mathrm{m}^{3}[1]$.

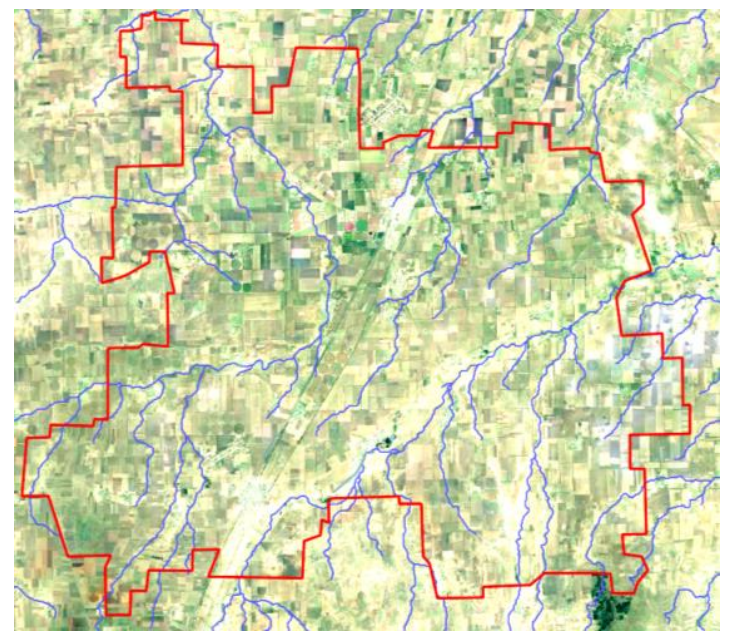

Fig. 3. Surface water resources.

The groundwater of the region belongs to the Belogorsk artesian basin, which occupies the syncline folds of the geological strata of the Neogene. The groundwater is confined mainly by the thick limestones of the Pont Mesotic and Middle Miocene age (Fig. 4).

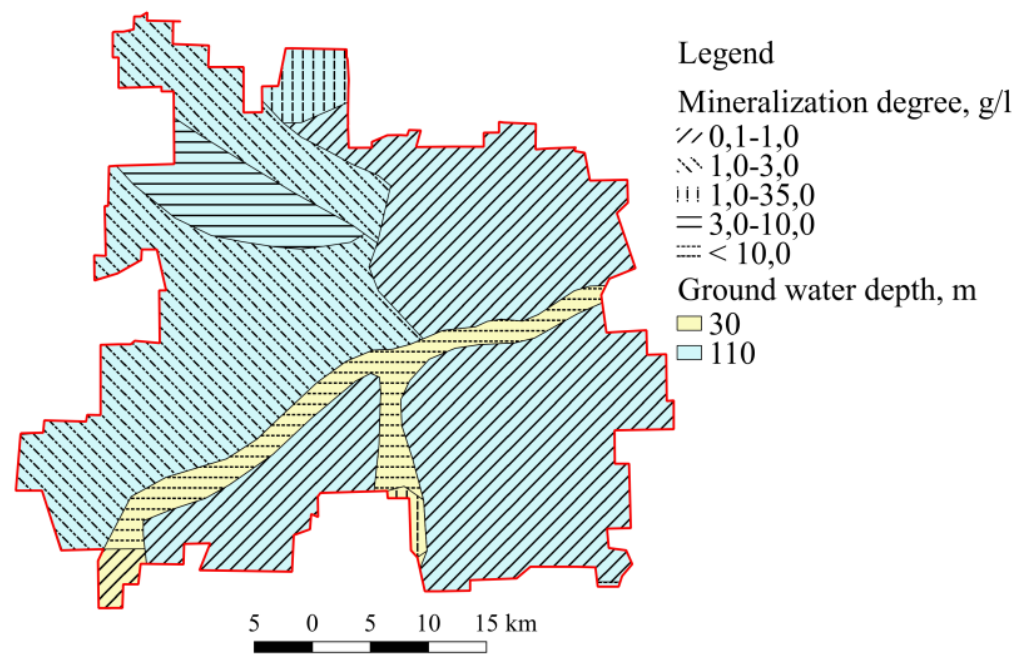

Fig. 4. Underground water resources (digitized map of Hydrogeological map of the Crimea. The groundwater, 1986). 
The peculiarity of Krasnogvardeysky district consists in its large amount of plowing, which is more than $80 \%$ of the area of agricultural land, at a time when the area under the pastures is only $6 \%$. Forests and shelterbelts in the region occupy only $2.3 \%$ of the area. Most of them were planted in the 50-60's of the last century and there is a tendency of its reduction in recent years, associated with natural loss, uprooting, felling and wildfire. The reduction of the areas under the forest belts leads to the wind erosion, dust storms, accompanied by the strong winds, which could demolish the upper fertile soil layer [5].

Grain crops are predominating in the structure of the cultivated areas of Krasnogvardeysky district, which account for more than $71 \%$ of all cultivated areas. This leads to the disruption of the crop rotation, the placement of grains for cereals for several years, the deterioration of the phytopathological situation, an increase in the number of pesticides and the deterioration of the ecological situation in the area [6].

Due to the fact that there is not enough surface water in the region, underground water is used for drinking water supply and irrigation of agricultural land. The quality of underground water was analyzed according to the protocols of the laboratory studies of the State Unitary Enterprise "Water of the Crimea" for the assessment of the water resources. Analyses of water quality parameters ( $\mathrm{pH}$ (hydrogen index), EC (conductivity), TDS (total dissolved solids), $\mathrm{C}^{\mathrm{o}}$ (temperature)) were conducted with the express methods using Hanna Combo pH/Conductivity/TDS Tester (HANNA Instruments Deutschland GmbH company) (https://hannainst.com/) and laboratory methods for chemical compounds determination (turbidity, hardness, salinity, alkalinity, chemical oxygen demand).

Water resources modeling was also carried out using the ArgSWAT 2009 (agrohydrological module in the ArgGIS 9.3 program). The Soil and Water Assessment Tool (SWAT) is a river basin or watershed scale model developed by Dr. Jeff Arnold for the USDA Agricultural Research Service (ARS). SWAT was developed for the prediction of the impact of land management activities on the water, as well as the impact of the sediment and agricultural chemical yields in large complicated watersheds with varying types of soils, land use and management conditions over the long periods of time [7].

DEM was downloaded as an output from the Shuttle Radar Topography Mission (SRTM). SRTM is an international project spearheaded by the National GeospatialIntelligence Agency (NGA) and the National Aeronautics and Space Administration (NASA) [8]. General information about land use and soil types was downloaded from the WaterBase project web-site (http://www.waterbase.org/download_data.html) and complemented by the local maps data. In addition, data can be obtained by the land use and soil digitized maps. Examples of SWAT applications and detailed description of the data loading and processing stages are indicated in the article [9-11].

There is one rain gage located on the territory of Krasnogvardeysky district - Klepinino station WMO ID 33939 (latitude $45.54^{\circ} \mathrm{N}$, longitude $34.53^{\circ} \mathrm{E}$, altitude above sea level 37 $\mathrm{m})$. Meteorological data was uploaded to database for the period 2005-2017.

\section{Results and discussions}

Water quality parameters of groundwater were analysed and mapped in QGIS 2.18 environment with the use of Interpolation tool (Inverse Distance Weighting method). Figure 5 shows the spatial distribution of the analysed parameters and describes the allowable limits of water content for drinking and irrigation purposes. The distribution of parameters across the territory showed a spatial unevenness in the quality of groundwater, due to the geological structure, the terrain and the groundwater table.

The assessment of the irrigation water quality by the ecological, hygienic and toxicological criteria was carried out according to State Standard (GOST 17.1.2.03-90). The parameters were normalized for drinking water: turbidity $<1.5 \mathrm{mg} / \mathrm{dm}^{3}$ (or $1.5 \mathrm{mg} / \mathrm{l}$ ); 
Hardness $<7.0 \mathrm{mmol} / \mathrm{dm}^{3}$; total mineralization $<1000 \mathrm{mg} / \mathrm{dm}^{3}$; alkalinity $<7.0 \mathrm{mmol} /$ $\mathrm{dm}^{3}$; Oxidability (Chemical oxygen demand) $<5,0 \mathrm{mg} / \mathrm{dm}^{3}$. The maximum permissible concentration of nitrates for drinking water is $45 \mathrm{mg} / \mathrm{dm}^{3}$, for fishery reservoirs $-40 \mathrm{mg}$ / $\mathrm{dm}^{3}$ for nitrates or $9.1 \mathrm{mg} / \mathrm{dm}^{3}$ for nitrogen.

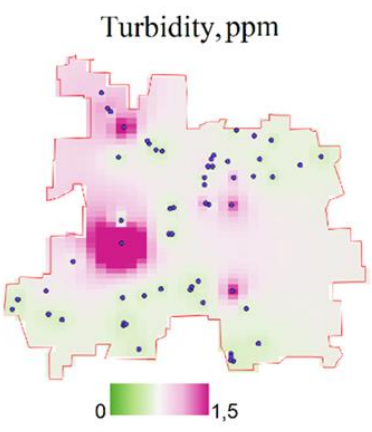

Alkalinity, mmol/l

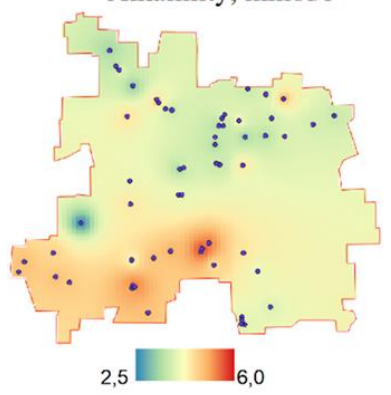

Hardness, mmol/1

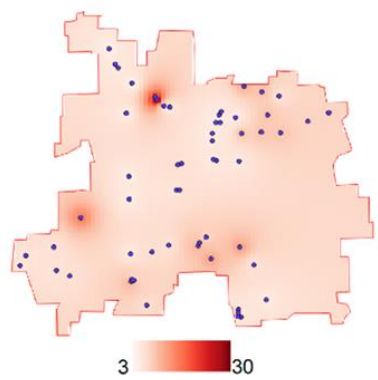

3

Chemical oxygen demand, ppm

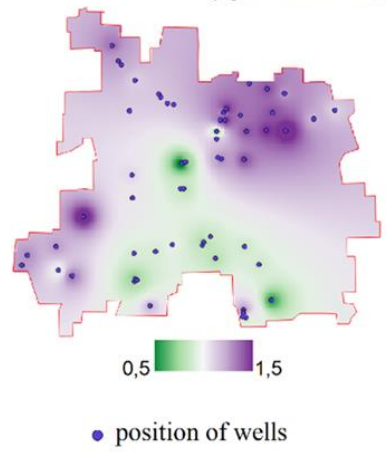

Salinity, ppm
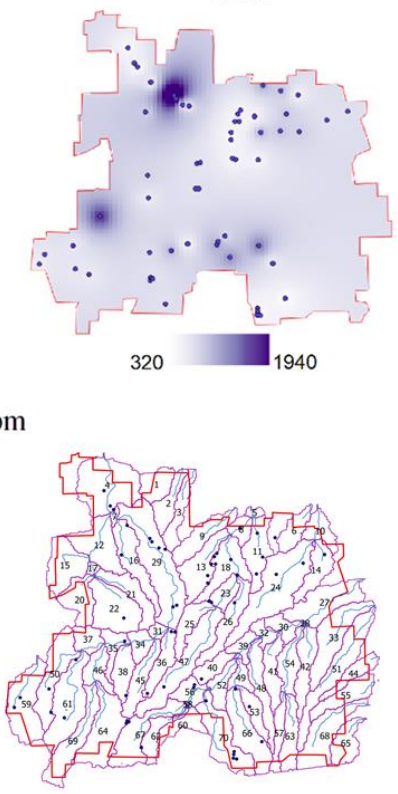

Fig. 5 Spatial distribution of groundwater quality parameters over the territory of Krasnogvardeysky district (April-May 2018).

Turbidity of water is an indicator characterizing the decrease in the transparency of water due to the presence of inorganic and organic fine dispersions, as well as the development of planktonic organisms. The reasons for the turbidity of water could be composed by the presence of the clay, inorganic compounds (aluminum hydroxide, carbonates of various metals), as well as organic impurities or living organisms. Also, the reason could be in the oxidation of iron and manganese compounds with air oxygen, which leads to the formation of colloids. The turbidity of drinking water is mainly normalized due to the fact that turbid water protects microorganisms under ultraviolet disinfection and facilitates the growth of bacteria, as well as for aesthetic reasons. High concentrations of particulate matter affect light penetration and productivity, recreational values, and habitat quality. Increased sedimentation and siltation may occur in streams, which may cause damage to fish and other aquatic habitats. Particles also provide attachment places for other pollutants, notably metals and bacteria. For this reason, turbidity readings could be used as an indicator of the potential pollution in a water body [12].

Hardness of water is a set of properties depending on the content of the alkaline earth elements, mainly calcium and magnesium ions. Stiffness above $10^{\circ} \mathrm{F}$ could cause the formation of slags in the water supply distribution system and scale under warming, depending on the $\mathrm{pH}$ and alkalinity of water. Water hardness less than $5^{\circ} \mathrm{F}$ can exert a corrosive effect on water pipes, and also affects the ease of usability for human consumption in terms of its taste [13]. Water is a great solvent for calcium and magnesium, 
so if the minerals are presented in the soil around a water-supply well, the hard water may be delivered to homes [14].

Total mineralization (salinity) is the total quantitative indicator of the content of substances dissolved in water. This parameter is also called the content of soluble substances or the total salt content, since the substances are usually dissolved in the water in the form of the salts. Inorganic salts (mainly bicarbonates, chlorides and sulphates of calcium, magnesium, potassium and sodium) are among the most common [15]. An elevated total dissolved solids (TDS) concentration is not health hazard. The TDS concentration is a secondary drinking water standard and it could be regulated. An increased total amount of dissolved solids may cause the water to have a bitter or salty taste; and also lead to the formation of inlays, films or precipitation on lamps; corrosion of luminaires and reduced efficiency of filters and water equipment [15].

The mineralization rates for technical water are stricter than for drinking water, because even relatively small concentrations of salts could spoil the equipment and settle on the walls of pipes, clogging them. The process of solontsation of the soil occurs because of the irrigation with saline water due to the high concentration of sodium chloride in the irrigation water. Permanganate oxidability of the water is the total concentration of consumed oxygen, corresponding to the amount of the permanganate ion expended during the treatment with this oxidizer under certain conditions of a specific water sample. Oxidability of water is the amount of oxygen, which is needed for the oxidation of organic substances in water. It is an indicator of the organic substances content. The lower the oxidability of water, the better its quality. A slight oxidation of water $\left(5-8 \mathrm{mg} \mathrm{O}_{2} / \mathrm{dm}^{3}\right)$ does not worsen the oxygen regime, and with a higher oxidizability $\left(10-15 \mathrm{mg} \mathrm{O} \mathrm{O}_{2} / \mathrm{dm}^{3}\right)$, the oxygen content in water decreases [16].

The alkalinity of natural or purified water is the ability of some of its components to bind an equivalent amount of the strong acids. The magnitude of alkalinity is judged on the direction of the geochemical and hydrochemical processes that determine the chemical composition of water, erosion of the earth's surface, the formation of sedimentary rocks, etc. Alkalinity is important for assessing the suitability of water for practical purposes. In industry and construction, the corrosion of building materials (concrete) depends on the value of alkalinity, the precipitation of carbonate scale in boilers feeding steam-power plants. In agriculture, the value of alkalinity determines the possibility of water usability for irrigation [17].

The map of the boundaries of the mineralization of groundwater in Krasnogvardeisky district was obtained by overlapping a digitized map of the Hydrogeological map of the Crimea (Fig. 3) and interpolation (IDW, QGIS 2.18) of mineralization (May 2018) (Fig. 6).

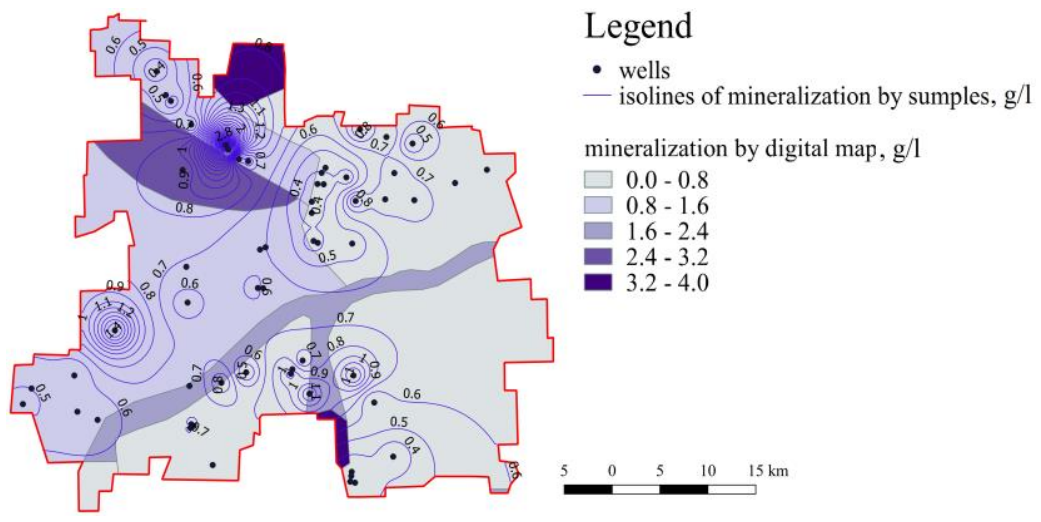

Fig. 6. Dynamic of mineralization of underground water (salinity). 
According to the previous research which showed convergence between statistic and simulated data of the water quality parameters [10], authors used SWAT model for the surface water quality parameters simulation. Whole basin of surface water resources in Krasnogvardeysky district is consist of 70 subbsins and 70 reaches (Fig. 7).
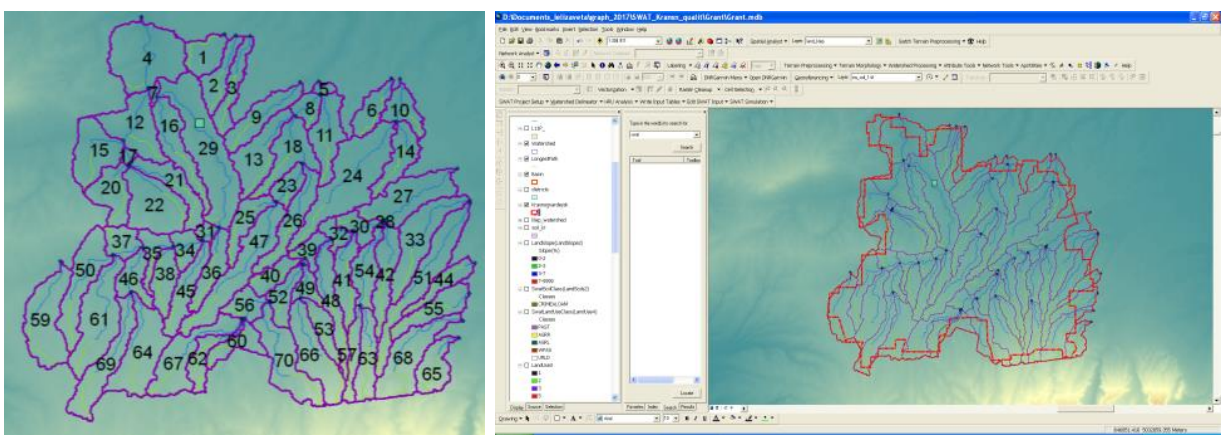

Fig. 7. Basin with reaches in ArcSWAT: left part - basins with meteorological station; right - with district border.

The results of modeling turbidity and NO3 (ArcSWAT 2009) in surface water (end of 2017 year) in riches and classified by concentration (Fig. 8) are presented below.
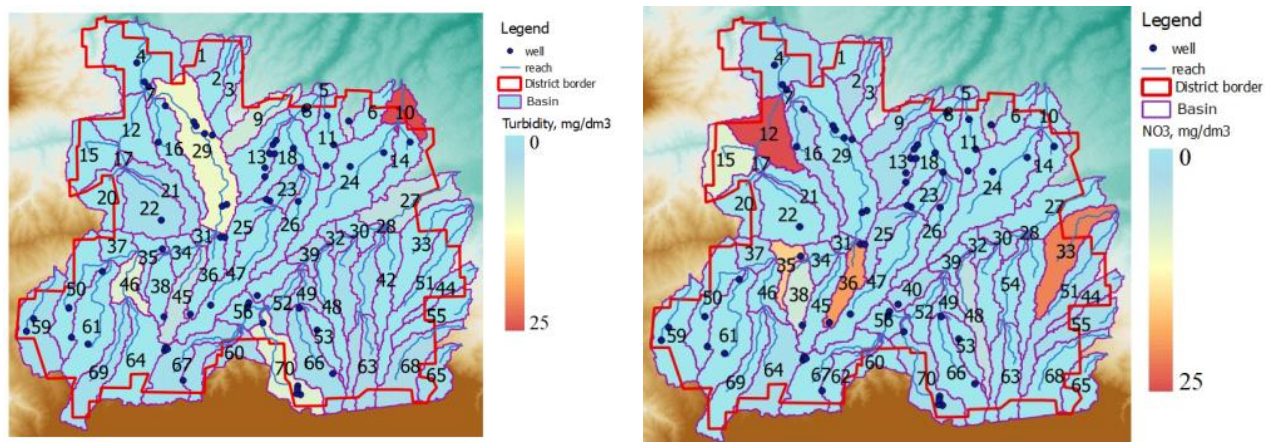

Fig. 8. Simulation of turbidity and NO3 concentration in surface water.

The pont-meiotic aquifer is operated by 8 farms in Krasnogvardeysky district, where the water salinity is $1.4-3.4 \mathrm{~g} / \mathrm{dm}^{3}$, according to the Ministry of Ecology and Natural Resources of Crimea deterioration of water quality for the period 2014-2018.

Results of the research show that turbidity, alkalinity and COD are within normal limits. Hardness of the water exceeds the MPC in the northern and eastern part of the area for drinking purposes and for irrigation, i.e. it is necessary to remove salts of calcium and magnesium, because it can lead to the soil deterioration. Mineralization of water does not meet the requirements that should be taking into account for drinking water usage purposes and also for the irrigation, because it may cause salinization of soil.

Water is suitable for irrigation when mineralization is less than $1 \mathrm{~g} / 1$, conditional suitable, when more than 1 to 2 . Only wells in eastern part of district can be used without purification on the drinking and irrigation purposes.

Spatial comparison of mineralization dynamics (1986-2018) shows no significant changes of parameters. Dependence between water quality in surface water sources and underground water is not revealed (turbidity $\mathrm{r}=-0,122112106 ; \mathrm{NO}_{3} \mathrm{r}=-0,141689145$ ). 
The proposed method is applicable for another soil properties research, especially hydrophysical properties of the soils [16-19] (water-retention capacity [18-20] and its hysteresis) [21, 22].

\section{Conclusions}

A spatial analysis of water quality parameters shows variation of them by the territory. Quality of surface and groundwater in general corresponds to required limits, but attention should be paid to the hardness and mineralization. Comparison of mineralization dynamics (1986-2018) showed that there are no significant changes of parameters. Dependence between water quality in surface water sources and underground water was not revealed (turbidity $\mathrm{r}=-0,122112106 ; \mathrm{NO}_{3} \mathrm{r}=-0,141689145$ )

Usage of the GIS environment allows visualizing spatial water quality parameters and simulating its dynamics. Also it could help water users to know the suitable places for water intake constraction.

\section{Acknowledgements}

The research was carried out as part of theme \#0834-2015-0015 and supported by Russian Foundation for Basic Research (\#16-04-01473-a).

\section{References}

1. A.A. Lisovskiy, V.A. Novik, Z.V. Timchenko, U.A. Gubsckaya, Surface water objects of the Crimea. Management and use of water resources. Handbook (Simferopol, 2011).

2. B.I. Streletz, Handbook on water resources. [Spravochnik po vodnym resursam], (Urozhay, 1987)

3. V.F. Popovych, Ie.A. Dunaieva, Ways to improve the efficiency of irrigated agriculture, 2(58), 114-120 (2015).

4. N.B. Khitrov, L.V. Rogovneva, Ie.A. Dunaieva, V.F. Popovych, V.S. Pashtetskyi, O.E. Klimenko, Taurida herald of the agrarian sciences, 1(5), 91-110 (2016).

5. A.A. Radchenko, Taurida herald of the agrarian sciences, 2, 77-79 (2013).

6. V.S. Pashtetskyi, Klepinino, 18 (2011).

7. S.L. Neitsch, J.G. Arnold, J.R. Kiniry, R. Srinivasan, J.R. WilliamsGrassland, Soil and Water Research Laboratory of Agricultural research Service and Blackland (Research centre of Texas Agricultural Experiment Station, Texas, 2011).

8. URL: http://gisweb.ciat.cgiar.org/sig/90m_data_tropics.html.

9. Ie.A. Dunaieva, V.F. Popovych, V.M. Paniutin, NUWMNRU, 3(55), $85-92$ (2011).

10. Ie. Dunaieva. Evaluation of Water Resources State Parameters with Using SWAT Model. International Journal of Engineering Research \& Technology (IJERT). 2, 9, 2162- 2167. (2013)

11. Ie.A. Dunaieva, Hydrotechnical amelioration, land reclamation, 99, 249-257 (2011).

12. U.S. Environmental Protection Agency (https://www.epa.gov)

13. URL: https://water.usgs.gov/edu/hardness.html

14. URL: https://www.water-research.net/index.php/water-treatment/tools/total-dissolvedsolids 
15. V.P. Vasilyev Analytical chemistry. Part 2. Physical and chemical methods of analysis [Analiticheskaya khimiya. Chast' 2. Fiziko-khimicheskiye metody analiza], Dropha, 384 (2003).

16. V.V. Terleev, A.O Nikonorov, I. Togo, Yu.V. Volkova, R.S. Ginevsky, V.A. Lazarev, E.R. Khamzin, V.V. Garmanov, W. Mirschel, L.I. Akimov, Magazine of Civil Engineering, 70(2), 84-92 (2017).

17. V.V. Terleev, A.O Nikonorov, R.S. Ginevsky, V.A. Lazarev, I. Togo, A.G. Topaj, K.G. Moiseev, V.A. Pavlova, K.A Layshev, M.V. Arkhipov, A.Yu. Melnichuk, I.A. Dunaieva, W. Mirschel, Magazine of Civil Engineering, 77(1), 141-148 (2018).

18. V.V. Terleev, W. Mirschel, U. Schindler, K.-O. Wenkel, Journal International Agrophysics, 24(4), 381-387 (2010).

19. N. Arefiev, V. Garmanov, V. Bogdanov, Yu. Ryabov, V. Terleev, V. Badenko, Procedia Engineering, 117, 26-31 (2015).

20. A. Makarov, A. Mihailova, N. Arefiev, S. Pavlov, T. Chashchina, V. Terleev, V. Badenko, Procedia Engineering, 117, 225-231 (2015).

21. V. Terleev, R. Ginevsky, V. Lazarev, A. Nikonorov, I. Togo, A. Topaj, K. Moiseev, E. Abakumov, A. Melnichuk, I. Dunaieva, IOP Conference Series: Earth and Environmental Science, 90, Article ID 012105 (2017).

22. S. Medvedev, A. Topaj, V. Badenko, V. Terleev, IFIP Advances in Information and Communication Technology, 448, 252-261 (2015). 